\title{
ГРОМАДСЬКА ДУМКА ЯК ІНДИКАТОР ПРОЦЕСУ ЗДІЙСНЕННЯ ОСВІТНІХ РЕФОРМ
}

Обстоюється думка, що в сучасному суспільстві на перший план виходять комунікативні методи управління, які передбачають перехід до самоорганізації суспільства на основі конструювання громадської думки. Стверджується, що попереднє формування громадської думки дає можливість впливати на просування соціальних інновацій, підтримка яких зумовлена причетністю суб'єктів суспільства до конструювання проекту цих інновацій. Наводяться та аналізуються результати всеукраїнського експерименту, спрямованого на формування позитивної громадської думки щодо освітніх інновацій. Громадська думка розглядається як засіб самоорганізації суспільства, який виконує функцію зворотного зв' язку в процесі конструювання спільного плану побудови майбутнього. Відповідно до запропонованого підходу конструювання громадської думки проходить у два етапи: спочатку визначається колективний автор майбутніх перетворень, коли задаються способи комунікації суб'єктів суспільства; на наступному етапі відбувається конструювання спільного соціокультурного проекту, який проявляється в громадській думці. Виявлено, що негативне ставлення представників різних соціальних груп до освітніх інновацій зумовлено здебільшого недовірою до держави як до автора реформ, який не враховує інтереси інших суб'єктів суспільства. Разом 3 тим декларована особиста зацікавленість учасників експерименту в реформуванні середньої освіти дає надію на можливість здійснення позитивних змін у системі освіти.

Ключові слова: громадська думка, складноорганізоване суспільство, соціокультурний проект, інновації, реформи освіти.

Проблема. В інформаційному суспільстві система освіти, готуючи учнів до функціонування в соціумі, що змінюється, не може сама залишатися незмінною. Якщо школа впродовж тривалого часу залишається незмінною, вона перестає виконувати свою функцію, не витримує конкуренції. Інші освітні інститути: інтернет, мода, масова культура, мистецтво, вулиця - залучають дітей набагато більше і навчають ефективніше, ніж школа [1]. Щоб відповідати вимогам динамічного світу, працівники системи освіти постійно мають удосконалювати свою професійну майстерність, упроваджувати в навчальний процес різноманітні інновації. Однак реформування освітньої системи в Україні викликає значні труднощі. Так, ставлення суспільства до пропонованого 12-річного терміну навчання в цілому було і є негативним [2; 3]. Про це свідчать зокрема, дані всеукраїнсь- 
кого опитування за 2015 рік: негативно ставляться до цього нововведення $72 \%$ працівників освіти та 70,8\% респондентів, у сім'ях яких $є$ учні або студенти (табл. 1).

Таблиия 1

Розподіл відповідей на запитання: “Як Ви ставитеся до перспективи запровадження в загальноосвітніх школах 12-річного терміну навчання?" $(y \%)$

\begin{tabular}{|l|c|c|c|}
\cline { 2 - 4 } \multicolumn{1}{c|}{} & $\begin{array}{c}\text { По вибірці } \\
\text { в цілому }\end{array}$ & $\begin{array}{c}\text { Серед праців- } \\
\text { ників освіти }\end{array}$ & $\begin{array}{c}\text { Серед респондентів, } \\
\text { у сім'ях яких } \\
\text { с учні та/або } \\
\text { студенти }\end{array}$ \\
\hline позитивно & 12,4 & 14,0 & 12,7 \\
\hline негативно & 69,3 & 72,0 & 70,8 \\
\hline важко відповісти & 13,9 & 12,0 & 13,1 \\
\hline не чув про таке & 4,4 & 2,0 & 3,4 \\
\hline
\end{tabular}

У зв'язку із цим Національною академією педагогічних наук у 2016-2020 роках проводиться всеукраїнський експеримент “Формування позитивної громадської думки щодо освітніх інновацій у навчальних закладах різного рівня". Він спрямований на формування позитивного ставлення педагогічних працівників, учнівської молоді, батьків і широкої громадськості до переходу загальноосвітніх навчальних закладів на 12-річний термін навчання, профілізації старшої школи, розширення практики державно-громадського управління освітою та інших заходів, спрямованих на підвищення якості освіти. У квітні - травні 2016 р. у межах підготовчого етапу дослідноекспериментальної роботи було проведено вхідний моніторинг 3 метою вивчення ставлення педагогічних працівників, учнівської молоді, батьків та широкої громадськості до переходу загальноосвітніх навчальних закладів на 12-річний термін навчання та профільне навчання в старшій школі.

Мета статті: презентація результатів проведеного дослідження.

Логіка суспільств перехідного періоду така, що, зрештою, упровадження інновацій означає розрив традицій, експорт сторонніх цінностей, можливість корекції цілей розвитку і т. ін. [4]. Соціокультурні практики, що діяли протягом тривалого часу, трансформуються, набуваючи нового якісного характеру [5]. В акторно-мережевій теорії (Actor-Network Theory) поширення інновацій звертається увага на взаємозв'язок будь-якої інновації та соціального контексту, який іії породжує [6]. В основі цієї теорії лежить перехід від моделі однорідного суспільства до структурних моделей диференційованого соціуму. Ін- 
новації розглядаються в певному соціальному контексті, де стикаються інтереси різних соціальних мереж або акторів і мереж. Кожна конкретна нова технологія $є$ лише елементом контексту взаємодії, а не центральним фактом, навколо якого вибудовується діяльність.

Виділяють п’ять стадій поширення інновацій: 1) пропозиція інновації (нової ідеї і технології з її упровадження) в якомусь фрагменті соціуму, обмеженого інтересами окремої соціальної мережі; 2) здобуття переваг, які отримують актори мережі, що використовують інновацію; 3 ) удосконалення інновації, щоб іiі можна було поширити i на інші фрагменти соціуму (розширення соціального контексту використання інновації); 4) упровадження інновації в соціум, використання мережею своїх переваг, отриманих у результаті впровадження інновації; 5) використання цієї інновації іншими мережами; зміна соціального контексту, коли запропонована інновація стає частиною буденного, звичного світу, в якому функціонують різні мережі, втрачаючи статус як новизни (“інновативності”), так і конкурентної переваги.

Успіх використання інновації в окремому сегменті суспільства змінює сформовану структуру взаємин у суспільстві, спонукаючи інші мережі використовувати інновації. Упровадження інновації - це складний колективний процес, у якому успіх залежить не так від ефективності конкретної інновації, як від організації соціального контексту, у якому передбачається іiі використовувати. "Споживання” інновацій, власне, зумовлено рішеннями і діями більш пізніх їх “користувачів”, яким надали можливість ознайомитися 3 перевагами використання нововведень. Як відомо, паперовий носій інформації винайдено в Китаї приблизно в XI столітті, однак книгодрукування з'явилося в Свропі п’ять століть потому. Саме тому при впровадженні нових технологій у робочий процес важливе значення має не тільки технічний, а й соціально-психологічний супровід.

Відомі способи соціального управління, що спираються на силовий, економічний або адміністративний тиск, можуть виявитися неефективними, якщо аудиторія (учні, батьки, роботодавці, система освіти і суспільство в цілому) не братиме активної участі в проведенні реформ [7]. Соціальні технології, засновані на тиску й примусі, активують енергію соціального протесту, напруженості, опору управлінському пресингу, що своєю чергою вимагає все нових і нових ресурсів для нарощування енергетики управління. Рано чи пізно такі технології ведуть до соціальних конфліктів і криз, виснаження ресурсів, соціальної нестабільності і т. ін.

Складноорганізовані системи стають чутливими до форми управлінських дій. Стиль управління не тільки визначає досяжність мети, а й впливає на керовану систему, причому результат цього впли- 
ву визначається самою системою. Операційна замкнутість соціальної системи дає підстави говорити про те, що певний зовнішній імпульс може лише зініціювати процес внутрішніх змін, тоді як кінцевий результат змін не визначений однозначно і $є$ наслідком внутрішньосистемних рекурсивних процесів. Соціальні інноваційні процеси пов'язані 3 динамікою операційно замкнутої самовпорядкувальної системи, 3 безперервністю іiі автопоезису, тому завдання управління інноваціями можна методологічно розглядати як завдання управління когнітивними процесами соціуму, його діяльністю, що породжує смисли, і рефлексією [8; 9]. Спільне моделювання соціального проекту, що передбачає його корекцію, забезпечує безперервність комунікації, а отже, і керованість системи.

Однією з основних причин поширення в суспільстві соціальних інновацій стають ефективні комунікації між проектною групою i суб'єктами суспільства, що дають змогу забезпечити підтримку пропонованих інновацій. Технології інформаційного супроводу досягають планованого соціального результату завдяки інформаційній підготовці відповідних рішень, що істотно зменшує активний опір змінам. Ці технології можна розглядати як засіб зниження агресивності, соціальної нестабільності в суспільстві. Це певною мірою справедливо і щодо маніпулятивних технологій. Вони не викликають протесту в публіки доти, доки не стають очевидними їх негативні цілі або сумнівні прийоми. У цьому випадку дієвість таких технологій стрімко падає.

Успіх реалізації будь-якого соціального проекту завжди залежить від якості пропонованої теоретичної моделі. Невдало побудована логічна конструкція, яка веде до сумнівних або руйнівних наслідків, зберігатиме свої властивості в будь-якому і кожному втіленні, що не дає надій на розв'язання жодної з актуальних проблем соціального устрою. В умовах зростання складності, невизначеності й відкритості світу наявність по-різному спрямованих суб'єктів дає змогу постійно вносити корективи в спільний проект. Ухвалення управлінських рішень у стилі жорсткої ієрархії і беззастережного дотримання інструкцій не вписується в логіку складноорганізованого світу, потребує інноваційного, творчого підходу, гнучкості, мобільності, орієнтації на корпоративну культуру. На перший план виходять комунікативні методи управління, які передбачають перехід до самоорганізації суб' єктів суспільного процесу на основі громадської думки, що спільно і повсякчас конструюється. Основним інструментом досягнення цілей цих суб'єктів стає попереднє їі формування, що дає можливість впливати на офіційні інститути влади.

Під громадською думкою розуміють артикуляцію суб'єктами суспільства наявного у них соцієтального дискурсу, що являє собою 
програму життєдіяльності і (ре)конструювання суспільства із закладеними в ній цілями розвитку (соціокультурний проект). Можна виділити три підходи до розуміння громадської думки, що відрізняються чутливістю оптики розгляду суспільства як автора соцієтального дискурсу. У межах філософського підходу суспільство розглядають як цілісність, а громадську думку трактують як вираження думки цього суспільства, тобто існує єдина громадська думка цілісного соціуму. Соціологи аналізують суспільство як безліч груп, об'єднаних у єдину цілісність (систему або систему систем). Відповідно, громадська думка складається 3 думок різних соціальних груп та існує у двох вимірах: громадська думка окремих соціальних груп і громадська думка цілісного суспільства. У межах соціально-психологічного підходу суспільство розглядають як цілісність, що складається із соціальних груп та індивідуальних суб'єктів, які до цих груп належать [10]. У цьому випадку громадська думка є частиною комунікації суб' єктів суспільства i являє собою текст текстів. Ї̈і можуть транслювати індивідуальні суб'єкти, групові суб'єкти (ЗМІ, громадські організації, “незалежні” аналітичні структури, соціальні мережі і т. ін.), суспільство в цілому (його інституційні структури). Але не всі вони є авторами соцієтального дискурсу, згідно з яким організовано функціонування суспільного життя. Існують автори (суб'єкти суспільства) приватних текстів зі своїми задумами, й існує автор глобального тексту суспільства, який інтегрує тексти всіх інших учасників, виходячи з власного задуму. Кожен індивідуальний суб'єкт є автором персонального тексту, але автором спільного тексту він може бути тільки в складі групового суб'єкта. Автор інтеграційного тексту виявляється в ході соціальних комунікацій суб'єктів суспільства, організація яких зумовлена особливостями устрою суспільства.

3 огляду на організацію громадської думки можна виділити низку їі функцій [11]. Вона може бути ілюстрацією наявного дискурсу, коли можна ознайомитися $з$ його змістом, спостерігаючи за діяльністю суб'єктів або їхніми комунікаціями. Вона $є$ інструментом комунікації суб'єктів, який організовує їхнє розуміння і слугує основою для ухвалення рішень про конструювання спільного дискурсу (спільного плану побудови майбутнього). Громадська думка дає змогу налагодити зворотний зв’язок у процесі конструювання спільного дискурсу, завдяки чому учасники цього процесу можуть оцінювати реалізацію задуманого і вносити в нього необхідні корективи [12]. Отже, громадська думка $\epsilon$ засобом самоорганізації суспільства, а управління процесами її конструювання через артикуляцію думки окремих груп у просторі соціальних комунікацій дає змогу цим групам здійснювати соціальний контроль над процесами конструювання соцієтального дискурсу. 
Виявом громадської думки є соціокультурні практики суб'єктів, їхні артикульовані тексти в просторі соціальних комунікацій, неявні задуми (власне ставлення до заявленого соціокультурного проекту). Прикладом видів громадської думки може слугувати відома казка про “нову сукню короля”. Наближені короля діють (несуть шлейф сукні), піддані демонструють своє захоплення новою сукнею, а дитина висловлює найпотаємніші думки дорослих.

Кожний можливий спосіб організації громадської думки (синкретична цілісність, система, текст текстів) увідповіднений щодо різних способів ії конструювання. У межах позитивістського підходу передбачається, що громадська думка (синкретична цілісність) уже реально конструюється чинними соціокультурними практиками. Життєдіяльність суспільства відбувається відповідно до громадської думки, виразником (і автором) якої є держава, котра в особі соціальних інститутів реалізує відповідну політику. 3 позиції конструктивістського підходу громадську думку (систему) слід проектувати, нормувати й упроваджувати за допомогою певного соціокультурного проекту. Завдання полягає в тому, щоб сконструювати спільний проект на основі відрефлексованих соціокультурних практик різних групових суб'єктів [13], і це відбувається в просторі соціальних комунікацій [14]. У межах синергетичного підходу конструювання громадської думки (тексту текстів) відбувається у два етапи. На першому етапі конструюється автор соціокультурного проекту, який задає способи комунікації суб'єктів суспільства, на другому - спільний соціокультурний проект, який виявляється в громадській думці.

Згідно 3 акторно-мережевою теорією поширення інновацій та синергетичним розумінням конструювання громадської думки можна запропонувати універсальну методику впровадження інновацій. Усередині суспільства виникає група суб'єктів, що пропонують інновації. Створюється певний дослідний полігон для їх упровадження, який дає змогу продемонструвати переваги їх використання. Для заповнення простору соціальних комунікацій ідеями необхідності пропонованих інновацій має бути утворена група, яка просуватиме соціальний проект у цьому просторі. Просування інновації залежить від взаємодії всіх трьох груп (творців, практиків, організаторів соціальних комунікацій), розширення складу їх учасників, причетності цих учасників до створення проекту. Без залучення самого суспільства до участі у створенні цього проекту тривалої його підтримки годі сподіватися. Будь-які, навіть найпрогресивніші, реформи не матимуть творчого характеру, якщо вони не будуть усвідомлені і підтримані більшістю населення. Але найголовніше те, що ці інновації повинні доводити свою спроможність у практиці всього суспільства, а не тільки окремого його анклаву. Як- 
що пропонується “недієздатна” реформа, щодо якої не враховано громадську думку, то, незважаючи на окремі успіхи, у довгостроковій перспективі зусилля реформаторів приречені на невдачу.

Для діагностики ставлення до пропонованих реформ освіти співробітниками лабораторії соціально-психологічних технологій Інституту соціальної та політичної психології НАПН України в межах емпіричного дослідження було розроблено анкету для педагогів, батьків та учнів 10-11 класів експериментальних шкіл. Анкета містила запитання, які дають змогу виявити ставлення респондентів до 12річного терміну навчання, профілізації старшої школи, інтеграції освіти в європейський освітній простір, а також твердження, що дають можливість оцінити передбачувані результати освітніх реформ.

В опитуванні взяли участь 768 респондентів з восьми областей України (Дніпропетровської, Житомирської, Київської, Львівської, Запорізької, Чернігівської, Херсонської, Хмельницької), з яких 369 осіб - он-лайн, 399 - оф-лайн. Серед респондентів було 139 чоловіків $(18,1 \%)$ та 624 жінки $(81,3 \%), 5$ осіб не вказали свою стать. Соціальний статус опитаних: директори шкіл - 26 осіб, педагоги - 327, учні - 47, батьки - 352, інші - 13, не відповіли - 1 особа. Дальшому аналізу підлягали відповіді директорів шкіл, педагогів, батьків. Щоб мати можливість порівнювати результати у всіх групах, ми наводимо їх у відсотках, але при цьому треба враховувати, що група директорів нечисленна і їхню думку можна розглядати як думку експертної групи.

Учасники експерименту, як виявилося, більш позитивно, ніж у суспільстві в цілому, ставляться до запровадження 12-річного терміну навчання в загальноосвітніх школах (табл. 2). Особливо це стосується директорів шкіл, хоча негативне ставлення серед вчителів і батьків превалює.

Таблиия 2

Розподіл відповідей на запитання “Як Ви ставитеся до перспективи запровадження в загальноосвітніх школах 12-річного терміну навчання?" $(y \%)$

\begin{tabular}{|l|c|c|c|}
\cline { 2 - 4 } \multicolumn{1}{c|}{} & Директори шкіл & Працівники освіти & Батьки \\
\hline позитивно & $\mathbf{5 0 , 0}$ & 28,1 & 20,2 \\
\hline негативно & 30,8 & $\mathbf{4 6 , 5}$ & $\mathbf{6 5 , 1}$ \\
\hline важко відповісти & 19,2 & 25,4 & 14,8 \\
\hline
\end{tabular}

Разом з тим більшість респондентів (серед учителів і батьків) вважають, що із запровадженням 12-річної освіти якість освіти не зміниться (табл. 3), а збільшення термінів навчання не буде позитивно 
впливати на якість отриманих знань (табл. 4), що послабить інтерес учнів до навчання (табл. 5). Куди, питається, подівся ентузіазм директорів шкіл щодо запровадження 12-річного навчання? Чи він був лише вимушеною необхідністю демонстрації лояльності щодо нав'язуваних згори реформ або ж вираженням соціальної бажаності щодо успішності процесу їх здійснення? Як бачимо, декларації про схвалення реформ поєднуються з невірою в їх ефективність.

Таблиия 3

Розподіл відповідей на запитання “ Чи підвищить, на Вашу думку, якість середньої освіти запровадження в загальноосвітніх школах

12-річного терміну навчання?" (у \%)

\begin{tabular}{|l|c|c|c|}
\cline { 2 - 4 } \multicolumn{1}{c|}{} & Директори шкіл & Працівники освіти & Батьки \\
\hline однозначно підвищить & 50,0 & 17,7 & 17,6 \\
\hline не змінить & 46,2 & 78,0 & 73,6 \\
\hline погіршить & 3,8 & 4,3 & 8,8 \\
\hline
\end{tabular}

Таблиия 4

Розподіл відповідей щодо твердження "Подовження терміну навчання загальноосвітній школі позитивно вплине на якість отриманих знань" (у \%)

\begin{tabular}{|l|c|c|c|}
\cline { 2 - 4 } \multicolumn{1}{c|}{} & Директори шкіл & Працівники освіти & Батьки \\
\hline так & 30,8 & 21,1 & 17,9 \\
\hline ні & 34,6 & 52,0 & 59,9 \\
\hline важко відповісти & 34,6 & 26,9 & 22,2 \\
\hline
\end{tabular}

Таблиия 5

Розподіл відповідей щодо твердження "Подовження терміну шкільного навчання до 12 років послабить зацікавленість дітей у навчанні, а школа перетворитися на “клуб знайомств” (у \%)

\begin{tabular}{|l|c|c|c|}
\cline { 2 - 4 } \multicolumn{1}{c|}{} & Директори шкіл & Працівники освіти & Батьки \\
\hline так & 65,4 & 71,6 & 58,8 \\
\hline ні & 15,4 & 18,3 & 21,0 \\
\hline важко відповісти & 19,2 & 10,1 & 20,2 \\
\hline
\end{tabular}

Цілком природно, що, не чекаючи позитивних результатів від запровадження реформи, більшість респондентів зробили висновок, що ідея 12-річного навчання в нашій країні не є вдалою (хоча серед учителів частка прихильників такої позиції найменша) (табл. 6). 
Таблиия 6

Розподіл відповідей щодо твердження “Збільшення терміну шкільного навчання за європейським зразком до 12 років не виправдовує себе в українських реаліях, є недоречним та фінансово невигідним" (у \%)

\begin{tabular}{|l|c|c|c|}
\cline { 2 - 4 } \multicolumn{1}{c|}{} & Директори шкіл & Працівники освіти & Батьки \\
\hline так & 57,7 & 38,5 & 61,9 \\
\hline ні & 15,4 & 27,8 & 17,1 \\
\hline важко відповісти & 26,9 & 33,6 & 21,0 \\
\hline
\end{tabular}

Основні причини недовіри батьківської громадськості до пропонованої інновації полягають у тому, що більшість батьків не вірить у сутність реформ, вважає їх імітацією. Натомість велика частка педагогів і директорів із цим не згодна, і це є непрямим показником усвідомлення необхідності реформ у цьому середовищі (табл. 7). Разом з тим більшість учителів і батьків (і трохи менше директорів) вважають, що при проведенні реформ держава керується тільки своїми інтересами (табл. 8).

Таблиия 7

Розподіл відповідей щодо твердження "Реформування освіти в Україні є малокерованим, непідготовленим процесом, який с скоріше імітацісю, а не справжнім реформуванням" (у \%)

\begin{tabular}{|l|c|c|c|}
\cline { 2 - 4 } \multicolumn{1}{c|}{} & Директори шкіл & Працівники освіти & Батьки \\
\hline так & 15,4 & 17,1 & 71,3 \\
\hline ні & 38,5 & 45,6 & 11,4 \\
\hline важко відповісти & 46,2 & 37,3 & 17,3 \\
\hline
\end{tabular}

Таблиия 8

Розподіл відповідей шодо твердження "При ухваленні змін у сфері шкільної освіти держава керусться своїми інтересами і не завжди враховує інтереси освітян, учнів та батьків" (у \%)

\begin{tabular}{|l|c|c|c|}
\cline { 2 - 4 } \multicolumn{1}{c|}{} & Директори шкіл & Працівники освіти & Батьки \\
\hline так & 53,8 & 73,1 & 73,3 \\
\hline ні & 15,4 & 11,0 & 12,8 \\
\hline важко відповісти & 30,8 & 15,9 & 13,9 \\
\hline
\end{tabular}

В основі негативного ставлення до 12-річного навчання лежить недовіра до держави як автора пропонованих реформ і невіра в те, що держава здатна реалізувати свої декларації, навіть ті, до яких у суспільстві позитивне ставлення. Прикладом слугує ставлення до профілі- 
зації старшої школи (табл. 9 - всеукраїнське опитування, табл. 10 опитування в рамках експерименту), яке поділяється суспільством. Більшість респондентів переконані, що через брак державного фінансування цю реформу буде проведено суто формально (табл. 11).

Таблиця 9

Розподіл відповідей на запитання “Як Ви ставитеся до профілізації старшої школи, шо передбачає поділ учнів після дев'ятого класу за успішністю для поглибленого вивчення певних предметів?" (у \%)

\begin{tabular}{|l|c|c|c|}
\cline { 2 - 4 } \multicolumn{1}{c|}{} & $\begin{array}{c}\text { По вибірці } \\
\text { в цілому }\end{array}$ & $\begin{array}{c}\text { Серед праців- } \\
\text { ників освіти }\end{array}$ & $\begin{array}{c}\text { Серед респондентів, } \\
\text { у сім'ях яких є учні } \\
\text { та/або студенти }\end{array}$ \\
\hline позитивно & 55,2 & 68,0 & 57,7 \\
\hline негативно & 28,4 & 20,0 & 27,8 \\
\hline важко відповісти & 11,4 & 8,0 & 10,5 \\
\hline не чув про таке & 5,0 & 4,0 & 4,1 \\
\hline
\end{tabular}

Таблиия 10

Розподіл відповідей на запитання "Як Ви ставитеся до профільного навчання у старшій школі?”' (у \%)

\begin{tabular}{|l|c|c|c|}
\cline { 2 - 4 } \multicolumn{1}{c|}{} & Директори шкіл & Працівники освіти & Батьки \\
\hline позитивно & 80,8 & 85,3 & 84,9 \\
\hline негативно & 3,8 & 5,5 & 6,6 \\
\hline важко відповісти & 15,4 & 9,2 & 8,5 \\
\hline
\end{tabular}

Таблиия 11

Розподіл відповідей шодо твердження "Профілізація старшої школи не забезпечена належною матеріально-технічною базою,

У ході опитування було виявлено, що негативне ставлення представників різних соціальних груп до освітніх інновацій зумовлене недовірою до держави як до автора реформ, який не враховує інтереси інших суб'єктів суспільства. Разом з тим більшість респондентів, що беруть участь в експерименті, декларують особисту зацікавленість у реформуванні середньої освіти (табл. 12), тобто націлені на здійснення реформ, що дає надію на можливість спільними зусиллями домогтися позитивних змін у системі освіти. 
Таблиияя 12

Розподіл відповідей на запитання "Чи можете Ви сказати, що відчуваєте особисту зацікавленість у реформуванні середньої освіти в Україні?"' (у \%)

\begin{tabular}{|l|c|c|c|}
\cline { 2 - 4 } \multicolumn{1}{c|}{} & Директори шкіл & Працівники освіти & Батьки \\
\hline однозначно так & 76,9 & 63,0 & 48,3 \\
\hline однозначно ні & 11,5 & 11,9 & 15,1 \\
\hline важко відповісти & 11,5 & 25,1 & 36,6 \\
\hline
\end{tabular}

Висновки. Ухвалення управлінських рішень з позиції жорсткої ієрархії і беззастережного дотримання інструкцій не вписується в логіку складноорганізованого світу, який вимагає інноваційного і творчого підходу, гнучкої мобільності та спрямованості на корпоративну культуру. Порівняно із силовими методами упровадження інновацій (авторитарного тиску, політичного диктату, різних форм соціального примусу і т. ін.) значно ефективнішими є методи переконування, формування громадської думки, відкритого діалогу різних соціальних груп, дискусій, громадських обговорень, соціальної реклами тощо.

Будучи індикатором успішної реалізації реформ, громадська думка дає змогу здійснювати соціальний контроль над процесом їх упровадження. Управління процесами конструювання громадської думки шляхом iї попереднього формування уможливлює керування процесами впровадження бажаних соціальних інновацій у сфері освіти.

Успіх соціальних інновацій досягається успішною практикою впровадження пропонованого проекту, ефективними комунікаціями між проектною групою і громадськістю, а також привабливістю цілей проекту для майбутньої життєдіяльності суспільства. Організаційна культура суспільства спрямована на задоволення довгострокових потреб усіх соціальних груп, пов'язаних спільністю інтересів і дотриманням етичних норм на всіх рівнях структури суспільства. Вона викликає довіру до організації суспільства в цілому та ініціатив його суб'єктів, що сприяє успішному саморозвитку соціуму. У тривалій перспективі незбіг цілей пропонованого проекту соціальних інновацій 3 отриманими результатами може звести нанівець ефективність комунікацій, за допомогою яких забезпечувалася підтримка суспільства на певному етапі розвитку реформ.

\section{Лimepamypa}

1. Андриянова О. Г. Школа - среда обитания будущего / О. Г. Андриянова // Образование и общество. - 2007. - № 5. - С. 79-82. 
2. Петрунько О. В. Освітні інновації в Україні: причини неефективності та можливості оптимізації [Електронний ресурс] / О. В. Петрунько // Теорія і методика професійної освіти. - 2012. - Вип 3. - Режим доступу: http://tmpe.eor.by/images/docs/3/12petioo.pdf

3. Суший О.В. Стратегічні пріоритети розвитку освіти у контексті європейської інтеграції України: чи стане реформа освіти запорукою успішних реформ в Україні у цілому? / О. В. Суший // Український соціум. - 2015. № 4. - C. 85-96.

4. Федотова М.Г. К содержанию понятия “транзитивное общество” / М. Г. Федотова // Вестник Вятского государственного гуманитарного университета. - 2010. - Вып. 4. - № 1. - С. 28-32.

5. “Хорошее общество”. Социальное конструирование приемлемого для жизни общества / отв. ред. В. Г. Федотова. - М. : ИФ РАН, 2003. - 183 с.

6. Latour B. Reassembling the Social: An Introduction to Actor-Network-Theory / B. Latour. - New York : Oxford University Press, 2005. - 301 p.

7. Сляднева Н. А. Социально-информационные технологии как синергетический фактор эволюции сложных социальных систем [Электронный ресурс] / Н. А. Сляднева // Информационно-аналитический журнал “Факт”. - 2001. - № 9. - Режим доступа : http://www.fact.ru/www/arhiv9s3.htm

8. Москалев И. Е. Методология и методика государственного управления инновационными социальными процессами / И. Е. Москалев // Образование и общество. - 2007. - № 5. - С. 62-69.

9. Хоріна О. І. Особливості конструювання рефлексивної технології супроводу освітніх та суспільних реформ (практичний аспект) / О. I. Хоріна // Навчання і виховання обдарованої дитини: теорія і практика. - 2016. - № 2. - C. 131-140.

10. Плющ А. Н. Синергетическая модель организации общества / А. Н. Плющ // Социологические исследования. - 2014. - № 10. - С. 14-22.

11. Петрунько О. В. Консолідувальний потенціал громадської думки: структурна, динамічна та функціональна складові / О. В. Петрунько // Проблеми політичної психології та іiі роль у становленні громадянина Української держави : зб. статей / Асоц. політ. психологів України, Ін-т соц. та політ. психології. - К. : Міленіум, 2013. - Вип. 14. - С. 207-214.

12. Іванченко C. М. Суспільний дискурс як спосіб організації інформаційного простору та формування громадської думки / С. М. Іванченко // Наукові студії із соціальної та політичної психології : зб. статей / Нац. акад. пед. наук України, Ін-т соц. та політ. психології. - К. : Міленіум, 2013. Вип. 32 (35). - С. 236-244.

13. Плющ А. Н. Технологии конструирования позитивного образа политических субъектов / А. Н. Плющ // Вісник Чернігівського національного педагогічного університету. - 2011. - Т. 2. - Вип. 94. - С. 83-90.

14. Іванченко С. М. Шляхи формування консолідованої громадської думки в цільових групах / С. М. Іванченко // Проблеми політичної психології : зб. статей / Асоц. політ. психологів України, Ін-т соц. та політ. психології. К. : Міленіум, 2014. - Вип. 1(15). - С. 267-273. 


\section{References}

1. Andriyanova, O. G. (2007). Shkola - sreda obitaniya budushchego [School is a habitat of the future]. Obrazovaniye $i$ obshchestvo [Education and Society], 5, 79-82 (rus).

2. Petrunko, O. V. (2012). Osvitni innovatsii v Ukraini: prychyny neefektyvnosti ta mozhlyvosti optimizatsii [Educational Innovations in Ukraine: the causes of inefficiency and opportunities for optimization]. Teoriia i metodyka profesiino $i$ osvity [Theory and Methods of Professional Education], 3, http://tmpe.eor.by/images/docs/3/12petioo.pdf (ukr).

3. Sushyi, O. V. (2015). Stratehichni priorytety rozvytku osvity u konteksti yevropeiskoi intehratsii Ukrainy: chy stane reforma osvity zaporukoiu uspishnykh reform v Ukraini u tsilomu? [Strategic priorities of education in the context of European integration of Ukraine: Will education reform key to successful reforms in Ukraine in general?]. Ukrainskyi sotsium [Ukrainian society], 4, 85-96 (ukr).

4. Fedotova, M. G. (2010). K soderzhaniyu ponyatiya "tranzitivnoye obshchestvo" [To the content of the concept of "transitive society"]. Vestnik Vyatskogo gosudarstvennogo gumanitarnogo universiteta [Bulletin of Vyatka State Humanitarian University], 1(4), 28-32 (rus).

5. Fedotova, V. G. (Eds.). (2003). "Khorosheye obshchestvo”. Sotsialnoye konstruirovaniye priemlemogo dlya zhizni obshchestva ["Good society". Social construction of an acceptable society]. Moscow: IF RAN Publ. (rus).

6. Latour, B. (2005). Reassembling the Social: An Introduction to Actor-NetworkTheory. N. Y.: Oxford University Press.

7. Slyadneva, N. A. (2001). Sotsialno-informatsionnyye tekhnologii kak sinergeticheskiy faktor evolyutsii slozhnykh sotsialnykh sistem [Social and informational technologies as a synergetic factor in the evolution of complex social systems]. Informatsionno-analiticheskiy zhurnal "Fakt" [Informational and analytical journal "Fact"], 9, http://www.fact.ru/www/arhiv9s3.htm (rus).

8. Moskalev, I. Ye. (2007). Metodologiya i metodika gosudarstvennogo upravleniya innovatsionnymi sotsialnymi protsessami [Methodology and methods of state management of innovative social processes]. Obrazovaniye i obshchestvo [Education and Society], 5, 62-69 (rus).

9. Khorina, O. I. (2016). Osoblyvosti konstruuvannia refleksyvnoi tekhnolohii suprovodu osvitnikh ta suspilnykh reform (praktychnyi aspekt) [Features of reflective technology design of educational and social reform support (practical aspect)]. Navchannia $i$ vykhovannia obdarovanoi dytyny: teoriia i praktyka [Training and education of gifted child: Theory and Practice], 2, 131-140 (ukr).

10. Plyushch, A. N. (2014). Sinergeticheskaya model organizatsii obshchestva [Synergetic model of society organization]. Sotsiologicheskiye issledovaniya [Sociological researches], 10, 14-22 (rus).

11. Petrunko, O. V. (2013). Konsoliduvalnyi potentsial hromadskoi dumky: strukturna, dynamichna ta funktsionalna skladovi [Consolidation potential of public opinion: structural, dynamic and functional components]. Problemy politichnoi psykholohii ta yii rol u stanovlenni hromadianyna Ukrainskoi derzhavy [The problems of political psychology and its role in the development of the Ukrainian state citizen], 15, 207-214 (ukr). 
12. Ivanchenko, S. M. (2013). Suspilnyi dyskurs yak sposib organizatsii informatsiinoho prostoru ta formuvannia hromadskoi dumky [Public discource as a way of organization of informational space and forming of public opinion]. Naukovi studii iz sotsialnoi ta politychnoi psykholohii [Scientific Studies in Social and Political Psychology], 32 (35), 236-244 (ukr).

13. Plyushch, A. N. (2011). Tekhnologii konstruirovaniya pozitivnogo obraza politicheskikh subyektov [Technologies for constructing a positive image of political subjects]. Visnyk Chernihivskoho natsionalnoho pedahohichnoho universytetu [Bulletin of Chernihiv National Pedagogical University], B. 2, Is. 94, 83-90 (rus).

14. Ivanchenko, S. M. (2014). Shliakhy formuvannia konsolidovanoi hromadskoi dumky v tsilovykh hrupax [Ways of consolidated public opinion forming in the target groups]. Problemy politychnoi psykholohii [The Problems of Political Psychology], 1(15), 267-273 (ukr).

Plyushch O. M., Khorina O. I., Tsysman V. E. Public opinion as an indicator for the process of educational reforms' implementation

Authors upgrade the idea that communicative management methods are coming to the fore in modern society. They require moving to self-organization of society on the basis of public opinion constucting. Previous forming of public opinion provides an opportunity to influence on the promotion of social innovations. Support of such innovations is conditional upon the involvement of civil society participants to the construction of project of such innovations. The results of allUkrainian experiment aimed on the forming of positive public opinion regarding educational innovations are presented and analyzed. Public opinion is considered as a tool for the self-organization of society. It performs the function of feedback during the creation of common plan of building the future. According to the approach proposed construction of public opinion goes through two stages: primarily the collective author of future transformations is defining, when the ways of communications between the subjects of society are specifying. On the next stage common sociocultural project, which reveals in the public opinion, is constructed. It was revealed that negative attitude of different social groups' representatives toward social innovations is based on the distrust towards the state as an author of these reforms, which doesn't take interests of other subjects of society into account. However, declared personal interest of participants involved in the experiment gives hope for the possibility of positive changes realization in the educational system.

Key words: public opinion, complex society, social and cultural project, innovations, educational reforms.

() Плющ О. М., Хоріна О. І., Цизман В. Е. 